\title{
Desenvolvimento de atividades de ensino de citologia para alunos com deficiências visuais: ações de educação inclusiva a partir da Teoria dos Contextos Comunicacionais ${ }^{1}$
}

\author{
Estéfano Vizconde Veraszto ${ }^{2}$ \\ Nathália Elisa Ferreira Vicente ${ }^{3}$
}

\begin{abstract}
Resumo
Para se ter uma Educação Inclusiva, faz-se necessário que haja materiais específicos que auxiliem com alunos com deficiência visual, para seu pleno desenvolvimento escolar, explorando outros sentidos e no último caso, ampliando imagens e objetos que diminuam o esforço visual para alunos com baixa visão. Todavia, em uma perspectiva inclusiva, o material deve servir também para alunos videntes. E muitas vezes isso não tem ocorrido no contexto escolar, onde o ensino de ciências, de uma maneira geral, tem se pautados em princípios visuais, perpetuando assim práticas excludentes. Partindo desses princípios, este trabalho mostra o desenvolvimento de atividades de ensino de citologia para alunos do ensino médio. A metodologia que norteou o trabalho é a de reflexẫo-na-açấo e a proposta foi elaborada buscando dialogar com a Teoria dos Contextos Comunicacionais. $\mathrm{O}$ resultado apresentado neste artigo pauta-se na concepção, elaboração e fundamentação de atividades inéditas, não pelo conteúdo específico, mas sim pela forma como foram desenvolvidas, embasadas em teoria específica da área de ensino de ciências para alunos com deficiência visual.
\end{abstract}

Palavras-chave: Educação Inclusiva. Deficiência Visual. Ensino de Citologia. Teoria dos Contextos Comunicacionais.

Development of cytology teaching activities for students with visual impairments: actions of inclusive education based on the Theory of Communication Contexts

\begin{abstract}
To achieve an inclusive education, it is necessary to have specific materials that help students with visual impairment, for their full school development, exploring the other senses and, in the last case, enlarging images and objects to reduce the visual efforts of students with low vision. However, in an inclusive approach, the material must be useful also to students without vision problems. Nevertheless, frequently this does not occur in the school context, where science education, in general, has been based on visual principles, thus perpetuating exclusionary practices. Based on these principles, this paper presents the development of cytology teaching for high school students. The methodology that guided the work is that of reflection-in-action and the proposal was elaborated based on the Theory of Communication Contexts. The result presented in this article is based on the conception, elaboration and foundation of unpublished activities, not by specific content, but by the way they were developed, based on specific theory of the area of science education for students with visual impairment.
\end{abstract}

Keywords: Inclusive education. Visual impairment. Teaching of Cytology. Theory of Communication Contexts.

\footnotetext{
${ }^{1}$ Pesquisa financiada pela Fapesp.

${ }^{2}$ Físico e Doutor em Educação Ciência e Tecnologia pela UNICAMP. Estágio doutoral na Universidad Complutense de Madrid. Professor Adjunto da UFSCar. Coordenador do Programa de Pós-Graduação em Educação em Ciências e Matemática da UFSCar Campus Araras. E-mail: estefanovv@gmail.com ${ }^{3}$ Graduanda em Ciências Biológicas pela UFSCar - Campus - Araras. Participa do Projeto de Extensão "Ensino de Ciências Biológicas e Inclusão" e do

Programa de Educaçáo Tutorial - PET. E-mail: nathaliaefv@gmail.com
} 


\section{Introdução}

A presença de alunos com necessidades educacionais especiais nas escolas brasileiras tem tido um acréscimo, haja vista que o censo escolar nacional de 2012 consta que, na rede regular de ensino em 1998, o número desses alunos, incluindo os portadores de deficiência visual (cegos ou com baixa visáo), era de 43.923 passando para 620.777 em 2012. Dessa forma, houve um aumento de 1313,4\%, o que nos remete às formas com que os professores poderão trabalhar para uma maior inserção desses alunos nas escolas (BRASIL, 2013).

Este fato reflete os efeitos de legislações específicas para a educação especial no Brasil e também está em consonância com as diretrizes educacionais na área e movimentos internacionais. Mesmo sabendo que a referida presença não garante a inclusão de fato desses alunos, sem ela intensificam-se relaçóes de uma sociedade excludente (CAMARGO et. al., 2009).

Além disso, no Brasil ainda precisa de muito mais escolas com infraestruturas adequadas que atendam diferentes tipos de necessidades. Nesse sentido, tomamos emprestado as palavras de Caiado (2006, p.1), quando questiona: Como manter acesa a utopia de incluir pessoas portadoras de algum tipo de necessidade especial [...] em uma sociedade que não resolveu sequer [...] a questão da inclusão das pessoas 'normais??

Assim, refletindo a partir deste prisma, é preciso considerar que, tanto professores atuantes no ensino regular, como aqueles que estâo em processo de formação, superem concepçôes pré-estabelecidas de que necessidades especiais são fatores limitantes e impeditivos no processo de ensino-aprendizagem.

Dentre deste cenário brevemente descrito, este trabalho buscou amparo na Teoria dos Contextos Significados, de Camargo (2012a) e também em resultados de pesquisas anteriores para fundamentar o desenvolvimento de atividades de ensino de biologia, mais especificamente Citologia, para alunos com deficiência visual (DV). O desenvolvimento dessas atividades, por si só, já consiste no objeto de investigação aqui apresentado, considerando que inexistem trabalhos na área de Ensino de Biologia que tratam da questão de inclusão à partir do referencial aqui adotado. Neste sentido, este artigo mostra os fundamentos e o desenvolvimento de atividades de ensino inclusivas, tratando especificamente de citologia, para aplicação em salas de aula inclusivas e considerando as necessidades educacionais especiais de alunos dom DV. Para tanto, a investigação buscou articular o referencial teórico com cada etapa do desenvolvimento das atividades, fundamentando assim sua concepção em teoria que trada da real necessidade de indivíduos que tenham algum tipo de DV. Neste sentido, para que esse objetivo principal se cumpra, algumas metas são traçadas:

- Fundamentação, concepção e desenvolvimento de atividades de ensino amparados em recursos multissensoriais e nas categorias propostas na Teoria dos Contextos Comunicativos (CAMARGO, 2012a);

- Planejamento e desenvolvimento de atividades para o ensino de citologia a partir dos pressupostos teóricos já mencionados, considerando também a utilização de materiais economicamente e ecologicamente viáveis;

- Viabilização de diferentes formas de percepção sensorial (visão e tato) sobre funçôes e estrutura de elementos celulares, mais especificamente a membrana plasmática, garantindo acesso aos alunos videntes e não videntes, para efetivar uma Educação Inclusiva. 


\section{Pressupostos teóricos}

Na sequência apresentamos os pressupostos teóricos investigados ao longo da etapa inicial da iniciação científica.

\section{Inclusão escolar}

Em um primeiro momento cabe destacar que a inclusâo contrapóe-se à homogeneização e normalização, defendendo o direito à heterogeneidade e à diversidade (MANTOAN, 2003). Neste sentido, a inclusão parte da lógica de que as diferenças individuais devem ser reconhecidas e aceitas por toda a sociedade, e devem ser os pilares para a construção de uma nova abordagem didática e pedagógica no ambiente escolar (RODRIGUES, 2003).

É pela diferença do outro que percebemos nossa identidade. Pensar a diferença como um elemento de fundamentação para a não discriminação social é libertar o homem, ou seja, é dar-lhe o direito de ser diferente. A diversidade tem por referencial central a multiplicidade e a convivência de elementos distintos (CAMARGO, 2012b). Assim, renegando qualquer ato excludente, a educação regular deve garantir a participação efetiva de todos os alunos, tenham eles necessidades educacionais especiais ou não, em cada atividade, ato ou dimensão escolar.

Conforme aponta Masini (2004), o termo inclusão, do verbo incluir (do latim includere), significa conter em, compreender, fazer parte de, ou participar de. Isso quer dizer que a inclusão escolar deve ser compreendida a partir do momento que o educando se sinta contido na escola, participando de todas as oportunidades que o sistema educacional oferece. Desta forma, na escola onde a inclusão é efetiva, não há discriminação e sim maior amparo aos alunos com necessidades especiais. Inclusão é olhar para as diferenças de todos(as) e trabalhar essas diferenças para um ensino-aprendizagem de forma comum. As açóes esperadas precisam considerar que o princípio fundamental da inclusão centra-se na valorização da diversidade (DENS, 1998).

\section{Deficiência Visual: conceitos}

A visão é vista como o canal mais importante de comunicação do indivíduo com o mundo, sendo caracterizada como essencial para um bom desempenho de ensino-aprendizagem, haja vista a dificuldade, de se inserir na sociedade e principalmente, nas escolas, pessoas com deficiência visual. Porém, estudos demonstram que a capacidade de enxergar não é algo consciente, ou seja, não é inata uma vez que é preciso aprender a ver (GIL, 2000). A capacidade de desenvolvimento de conhecimento e aprendizado dos alunos portadores de deficiência visual é, segundo Santos e Manga (2009), a mesma dos alunos que possuem uma visão normal, sendo necessárias apenas adaptaçóes e utilização de recursos especiais.

O termo Deficiência Visual abrange desde pessoas que possuem baixa visão, até pessoas que possuem a cegueira. Por baixa visão, podemos entender às alteraçôes da capacidade ocular, como reduçáo do campo visual e da sensibilidade à contrastes de luz e sombra e, a incapacidade de enxergar com clareza a uma distância de 3 metros, percebendo apenas vultos (CARVALHO et. al., 1994). 
A cegueira, também conhecida pela perda total da visão, pode ser adquirida ou congênita (desde o nascimento). A pessoa que perde a visão posteriormente, possuí o que chamamos de memória visual, ou seja, ela consegue lembrar, mesmo com a perda da visão, as imagens e cores que conheceu. Esse fator é importante para o processo de readaptação pois, quem nasce sem a visão jamais terá uma memória visual e dessa forma, suas referências de percepção de mundo irão abranger e desenvolver os outros quatro sentidos: audição, olfato, paladar e tato (MASINI, 1994). Elencado a isto, cabe ainda apontar que os indivíduos com deficiência visual precisam de ambiente estimulador, bem como precisam de mediadores e condições favoráveis para explorar seu referencial perceptivo particular. Além disso, não são pessoas diferentes de seus colegas videntes no que diz respeito à capacidade de aprender, à curiosidade, aos interesses, motivaçóes e demais aspectos relacionados à formação de identidade e aos processos de desenvolvimento e aprendizagem (SÁ; CAMPOS; SILVA, 2007).

Na medicina, uma pessoa é considerada cega quando a visão corrigida do melhor olho é de 20/200 ou menos, ou seja, se ela pode ver à 20 pés (6 metros) o que uma pessoa de visão normal poder ver a 200 pés (60 metros). É também considerada cega se o diâmetro mais largo do seu campo visual subentende um arco não maior de $20^{\circ}$ (CONDE, 2012).

Em seu ensaio "O menino cego", Vygotsky (1997) aborda a evolução da concepção social sobre cegueira a partir de três etapas históricas: mística, biológica e científica. Na etapa mística, que trata-se da Antiguidade, havia uma concepção preconceituosa em relação ao cego, associando-o como incapaz e infeliz. Porém, também era associado àquele ser capaz de ter acesso à visão espiritual. Dessa forma o dom filosófico estaria relacionado a cegueira. A etapa biológica no século XVIII, o senso comum é substituído pela ciência, a partir disso o cego é incorporado à sociedade e à cultura através da educação. Nesse período, acreditavam-se que a cegueira seria compensada pelo desenvolvimento dos outros órgãos do sentido.

A terceira etapa da evolução de concepção sobre a cegueira, é a cientifica ou sociopsicológica, que teve origem na Idade Moderna e traz a ideia da compensação social. O que Vygotsky (1997) acreditava era que não existia de fato uma reestruturação comportamental do indivíduo cego, ou seja, não se compensava a cegueira com o desenvolvimento dos outros sentidos, mas sim uma compensação social na qual o cego busca superar as barreiras sociais e se estabelecer socialmente. Sendo assim a cegueira não é uma deficiência, mas as consequências da inclusão de uma pessoa cega em sociedade, poderão limitar seu desenvolvimento completo.

A cegueira em si não faz a criança deficiente, não é um defeito, uma deficiência, uma carência, uma enfermidade. Chega a ser só em certas condições sociais de existência do cego. É um signo da diferença entre sua conduta e a conduta dos outros. A educação social vencerá a deficiência (VYGOTSKI, 1997, p. 82).

O ensino brasileiro tem se pautado em princípios visuais, perpetuando assim, práticas excludentes. É necessário equiparar as escolas e os professores para ser ter uma total inclusão desses alunos cegos. Pesquisas na área indicam que a utilização de recursos de apoio, sejam eles maquetes táteis, recursos auditivos, tecnologias assistivas, dentre outros, é requisito fundamental para o ensino de ciências para indivíduos deficientes visuais. Além disso, também são apontados indícios de que a sociedade como um todo deve participar do 
processo inclusivo e que a infraestrutura das instituiçóes de ensino precisa ser adequada e adaptada às diferentes necessidades.

\section{Ensino de Ciências Biológicas para alunos cegos}

Dentre vários desafios inclusivos, um dos maiores é o de ensinar conceitos e fenômenos naturais e científicos para alunos com deficiência visual. Essa consideração se ampara em estudos realizados na área (CAMARGO, 2016, 2012a, 2012b, 2011, 2010, 2008; CAMARGO, NARDI, 2010, 2008, 2007, 2006a, 2006b; CAMARGO, NARDI, CORREIA, 2010; CAMARGO, NARDI, VERASZTO, 2009, 2008a, 2008b, CAMARGO et. al., 2013, 2009) e também na colocação de Masini (1994) que afirma que o ensino é pautado em padróes adotados para alunos videntes. Postura que exclui os alunos deficientes visuais do processo de ensino-aprendizagem.

A inclusão de alunos deficientes visuais em aulas regulares de ciências biológicas têm sido um dos desafios da educação inclusiva mais delicados, considerando que modelos científicos vigentes, bem como as metodologias empregadas no ensino, quase sempre são apoiadas na visão como sendo um sentido fundamental para garantir uma suposta aprendizagem na área (MASINI, 1994, 2002).

Dessa forma, podemos concluir, que o deficiente visual permanece oculto na cultura de videntes, que não levam em conta suas formas diferentes de percepção. E assim, surgem questôes que necessitam de análise crítica e precisa: como ensinar sobre ciências e, mais precisamente, sobre citologia, para um cego congênito, sendo que os mecanismos de apoios educacionais são visuais? Como inserir atividades de ensino-aprendizagem que leve em conta a inclusão, uma vez que as instituiçôes de ensino são totalmente excludentes?

Para responder a essas questôes, Masini (1994) traz o entendimento das percepçóes do deficiente visual, ou seja, é necessário buscar o sentido que objetos e fenômenos têm para o aluno cego.

Um bom exemplo, [...] é o uso da bengala pelo cego. [...] Ele não mais começa da epiderme da mão, mas na ponta do bastão. Através das sensaçóes produzidas pela pressão do bastão na mão [...]. A bengala não é mais um objeto que o cego perceberia, mas um instrumento com o qual ele percebe (MASINI, p. 31, 1994).

É fundamental que a escola e o professor estejam capacitados para trabalhar diversas formas pedagógicas de ensino inclusivo. Observa-se o grande empenho em materiais didáticos de citologia para cegos, porém nenhuma atividade didática. Os materiais didáticos auxiliam nas atividades de ensino, já as atividades didáticas são um conjunto de procedimentos mediadores da reação entre os alunos e os objetos de ensino, levando em conta as relaçôes sociais no processo pedagógico. Uma vez que não há investimentos em atividades de ensino para cegos, não há total inclusão, pois não levamos em conta as diferentes formas de compreensão dos alunos. É preciso que as atividades de ensino atendam tanto videntes quanto alunos com deficiência visual, assim será totalmente inclusivo.

Além disso, aqui também cabe destacar que pesquisas anteriores relacionadas com este trabalho, buscaram entender como professores em formação entendem o processo de conceitualização em ciências por 
indivíduos com DV (VERASZTO, CAMARGO, CAMARGO, 2017, 2016a, 2016b, 2016c; VERASZTO; CAMARGO, 2015; VERASZTO et. al., 2014). Essas investigações sinalizaram que a compreensão acerca do processo de aprendizagem de conceitos científicos por indivíduos cegos congênitos ainda estabelece fortes relaçóes com o senso comum. No geral, muitos indivíduos apontam que um indivíduo com deficiência visual não consegue aprender ciências, ou só poderá vir a conhecer conceitos científicos mediante apoio e mediação social. Se, por um lado a questão da mediação social mostra uma consciência acerca da efetivação de processos inclusivos em todos os níveis de ensino, por outro, existe ainda uma opiniāo fortemente arraigada no senso comum que coloca o indivíduo cego (ou com DV) como sendo incapaz de aprender ciências.

O projeto trata-se de uma proposta de desenvolvimento de atividades de ensino inclusivas, que aborde Ciências Biológicas - Citologia - que servirá de apoio para professores atuantes e/ou em formação, além, claro, de ser destinados a todos os alunos, de forma que contemple aqueles que têm diferentes tipos de deficiências visuais. Desta forma, considerando o ensino de Biologia para alunos com deficiência visual, simultaneamente duas questōes foram levantas:

- Quais as melhores estratégias para o desenvolvimento de material didático inclusivo sobre citologia membrana plasmática, uma vez que o ensino tradicional tem se amparado em pressupostos visuais e muitas vezes excludentes?

- De que forma é possível que as atividades de ensino e os materiais didáticos desenvolvidos sejam economicamente viáveis para escolas de ensino público?

Desta maneira, essas duas questões nortearam o desenvolvimento do projeto e foram ponto de partida para todas as iniciativas e investigações a serem desenvolvidas. Contudo, é preciso apontar ainda que essas questôes foram colocadas pois o ensino de Ciências Biológicas dentro das escolas ocorre quase sempre de forma visual e faltam recursos que atendam às necessidades e diversidades de todos os alunos, buscando equidade no ensino.

Também vale destacar que, já que a proposta da pesquisa visa o atendimento do ensino público, faz-se necessário que o material didático esteja dentro das condiçôes financeiras do público alvo pretendido, além de que seu desenvolvimento também deva se atentar para com o cuidado com a natureza, na busca por uma proposta interdisciplinar e sustentável.

A importância da valorização da diversidade sensorial é que a mesma permite com que estudantes videntes ou com deficiências visuais compartilhem de experiências de aprendizagem de conteúdos científicos em comum, explorando cada qual, suas potencialidades perspectivas distintas.

A busca por outros trabalhos que tratam da mesma temática foi empreendida para auxiliar na fundamentação deste projeto. Todavia, poucos trabalhos foram encontrados e os mesmos não abordam o tema da maneira como aqui é proposto (PIRES, JORGE, 2014). Esse ponto auxilia na percepção da relevância de investigaçôes na área de inclusão do aluno com deficiência visual nos estudos escolares. Todavia, necessita-se de materiais específicos e, como isso em suma não ocorre, a elaboração do mesmo é importante para que o processo ensino-aprendizagem de Biologia se torne mais significativo. A exploração de algo concreto e não apenas imaginável contribuirá para a participação plena do aluno com o meio escolar. 


\section{Pressupostos teóricos para elaboração de atividades de ensino de ciências para deficientes visuais}

Segundo Camargo (2012a), categorias foram criadas para interpretação de atividades de ensino de ciências para deficientes visuais. É a partir dessas categorias que o projeto buscou desenvolver as atividades, pois leva em conta processos de ensino-aprendizagem de ciências de forma comunicativa e sensorial. A partir da interpretação dessas colocaçóes de Camargo (2012a), que buscamos relacionar o processo comunicativo entre diferentes alunos e professores. Considerando os objetivos das propostas, será utilizada apenas a categoria comunicação como norte metodológico para elaboração das atividades de ensino.

A categoria Comunicação busca identificar quais as condições de acessibilidade da linguagem que podem dar suporte às informaçóes veiculadas durante atividades de ensino e aprendizagem, como por exemplo, materiais que considerem o tato como um meio de aprendizagem. Também discute a influência da ausência da visão no compartilhamento de significado entre vidente e deficiente visual acerca das informaçóes veiculadas, pois a percepção e entendimento de um cego atende à diferentes perspectivas das quais estamos acostumados a seguir como linha de raciocínio.

Dessa forma, a categoria norteou o planejamento das atividades, no sentido de considerar que as estruturas empírica e semântico-sensorial da linguagem possibilitem o estabelecimento de relaçóes comunicativas entre os sujeitos com e sem deficiência visual. De forma complementar, ainda é possível acrescentar que esta categoria é dividida em duas subcategorias:

\section{Estrutura empírica da linguagem}

Essa categoria refere-se à identificação do suporte material da linguagem. Isso significa que a categoria trata da forma pela qual determinada informação é materializada, armazenada, veiculada e percebida, ou seja, é o conhecimento adquirido a partir de experiências. Neste sentido, a estrutura empírica pode ser organizada em estruturas fundamentais (códigos visuais, auditivos e táteis), e estruturas mistas (quando os códigos se combinam), segundo aponta Camargo (2012a).

- Estruturas fundamentais

- Fundamental auditiva: possui apenas códigos sonoros; o acesso às linguagens com essa estrutura empírica se dá por meio da observação auditiva dos mencionados códigos.

- Auditiva e visual independentes: caracteriza-se pela independência entre os códigos auditivo e visual. Por exemplo, vale apontar que ocorre quando se projetam e se falam as mesmas informaçôes de forma independentes; assim, o nível do detalhamento oral determina padróes de qualidade de acessibilidade às informaçóes veiculadas.

- Tátil e auditiva independentes: caracteriza-se pela independência entre os códigos tátil e auditivo. Pode ser identificada em situaçôes de ensino-aprendizagem onde um indivíduo com deficiência visual entra em contato com conteúdos através de práticas que envolvam o tato e a audição.

- Fundamental visual: é constituída por códigos exclusivamente visuais; isso implica que o 
receptor da mensagem veiculada tem acesso às informaçôes somente através de observação visual. Trata-se de uma situação que deve ser evitada na elaboração das atividades previstas neste projeto.

- $\quad$ Estruturas mistas

- Áudio-visual interdependente: caracteriza-se pela dependência mutua entre os códigos auditivo e visual que dão suporte à veiculação de informaçôes; o acesso às linguagens com esta característica somente pode se dar por meio da observação simultânea dos códigos mencionados, já que a observação parcial de um dos códigos não desfaz a interdependência de seu suporte material.

- Tátil-auditiva interdependente: caracteriza-se pela dependência mútua entre os códigos tátil e auditivo que dão suporte à veiculação de informaçóes. Com essas características, o acesso às linguagens pode se dar somente através da observação simultânea dos códigos mencionados, pois a observação parcial de um dos códigos não desfaz a interdependência de seu suporte material.

\section{Estrutura semântico-sensorial da linguagem}

Essa estrutura é caracterizada quando as informações são entendidas por meio das percepções sensoriais em função da interpretação dos efeitos produzidos pelas percepçóes sensoriais nos significados veiculados durante práticas de ensino-aprendizagem. Esses efeitos são entendidos por meio de quatro referenciais que associam significado e percepção sensorial:

\section{- Significados indissociáveis}

São aqueles cuja representação mental é dependente de determinada percepção sensorial; esses significados nunca poderão ser representados internamente por meio de percepçôes sensoriais distintas das que os constituem. Busca o compartilhamento dos significados psicológicos, inicialmente na consciência do emissor e posteriormente na consciência do receptor.

- Significados indissociáveis de representaçóes visuais: somente podem ser registrados e internamente representados por meio de códigos e representaçóes visuais. Neste sentido, Vigotski (1997), aponta que os significados indissociáveis de representaçóes visuais são inacessíveis às pessoas cegas de nascimento, já que as mesmas não compreendem o fenômeno luminoso em seu âmbito visual, e sim a partir dos significados sociais a tal fenômeno relacionados (VIGOTSKI, 1997). Desta maneira, a cegueira congênita em nada se assemelha à sensação visual de um vidente com os olhos vendados. O cego total de nascimento náo vive envolvido na escuridão, já que as ideias de claro, escuro, cores, etc, não possuem significado visual para tal pessoa.

- Significados indissociáveis de representaçóes não-visuais: somente podem ser registrados e internamente representados por meio de códigos e representaçôes não-visuais. $\mathrm{O}$ acesso e compreensão de fenômenos que contêm esses significados são dependentes da observação 
não-visual, na medida em que não são possíveis o registro externo e a representaçáo interna dos mesmos por meio de códigos e imagens visuais.

\section{- Significados vinculados}

São aqueles cuja representação mental não é exclusivamente dependente da percepção sensorial utilizada para seu registro ou esquematização, podendo sempre ser representados por meio de percepções sensoriais distintas da inicial.

- Significados vinculados às representaçóes visuais: são significados registrados por códigos visuais e observados pelo olho. Por esse motivo tornam-se representados internamente por imagens mentais e sempre poderão ser registrados e internamente representados por meio de códigos e representaçóes não-visuais.

- Significados vinculados às representaçóes náo-visuais: são significados registrados por códigos não-visuais e observados pelo tato, audição etc.; tornam-se, por este motivo, representados internamente por imagens mentais não-visuais e sempre poderão ser registrados e internamente representados por meio de códigos e representaçóes diferentes das que os constituem. Assim, há para o caso da indissociabilidade, uma relação inseparável entre significado e percepção sensorial, enquanto que, para o caso da vinculação, não.

\section{- Significados sensorialmente náo relacionáveis (ou sem relaçáo sensorial)}

Não possuem vínculo ou associação com qualquer percepção sensorial. Embora o indivíduo possa construir representaçóes mentais sensoriais acerca de ideias com a presente característica, as mesmas nunca corresponderão de fato aos fenômenos/conceitos que se visam comunicar. As representaçôes mentais com esta característica sempre estaráo no nível analógico, metafórico e artificial, sendo, portanto, carregadas de significados abstratos referentes a construtos hipotéticos elaborados para a explicação de fenômenos, efeitos, propriedades etc.

\section{- Significados de relacionabilidade sensorial secundária (ou de relação sensorial secundária)}

São aqueles cuja compreensão estabelece com o elemento sensorial uma relação não prioritária. Ou seja, embora ocorram construçôes de representaçōes mentais sensoriais por parte do aprendiz, as mesmas não representam pré-requisito à compreensão do fenômeno/conceito abordado.

Em suma, os significados de conceitos que não possuem associação com nenhuma percepção sensorial encontram-se analisados na subcategoria "não relacionabilidade", ou seja, mesmo que o entendimento seja mental sensorial, não vai corresponder o que visa comunicar; já os significados de conceitos cujas representaçôes internas associam-se a esquematizaçôes externas não fundamentais para seu entendimento ou compreensão, encontram-se analisados na subcategoria "relacionabilidade secundária", ou seja, a compreensão não estabelece relação prioritária com elementos sensoriais.

Como já mencionado, a ideia de "categorias" fundamenta-se nos conceitos de "representaçôes internas" ou "representaçóes mentais", que ocorrem no nível subjetivo da cognição, do pensamento. Em outras 
palavras, tais representaçóes referem-se às formas em que codificamos características, imagens, propriedades, sensaçôes, etc, de um objeto percebido ou imaginado, ou também de um conceito abstrato.

Por fim, é importante apontar que estes pressupostos teóricos, aqui brevemente descritos a partir da teoria de Camargo (2012a), serão aprofundados na fundamentação teórica, como o intuito de trazer esses elementos de maneira mais sólida para a delimitaçâo metodológica ao longo do desenvolvimento da pesquisa. Desta forma, a principal contribuição desta pesquisa será a de propor alternativas de metodologias para o ensino de ciências em uma perspectiva inclusiva.

\section{Delimitações metodológicas}

Este trabalho fundamenta-se em pressupostos metodológicos próprios de uma abordagem qualitativa, utilizando técnicas de pesquisa descritiva e analítica.

Além disso, a pesquisa adotou também o conceito de reflexão-na-ação, definido por Schön (1992). Esse pressuposto trata-se de um processo mediante o qual os profissionais aprendem partindo da análise e interpretação da sua própria atividade.

Neste sentido, as práticas que nortearam o desenvolvimento das atividades de ensino descritas em tópicos subsequentes serviram como ponto de partida para criação de conhecimentos específicos. Em outras palavras, os resultados obtidos nesta investigação só foram possíveis através do contato dos pesquisadores envolvidos com a prática através da elaboração de atividades inclusivas para o ensino de citologia. Os resultados dessas reflexóes agregam-se na descrição das atividades e também na análise apresentada nas consideraçôes finais do texto.

\section{Métodos e técnicas para o planejamento das atividades}

Um elemento chave do ensino eficaz está no planejamento de atividades de ensino, pois é a partir dele que os objetivos de aprendizagem e as decisões metodológicas serão desenvolvidos. Dessa forma o planejamento de atividades deve apresentar:

- Conceitos: membrana plasmática das células;

- Objetivos: compreender o conceito de célula e sua estrutura principal - membrana plasmática, relacionando a respectiva organela às suas respectivas funções, podendo diferenciar célula procarionte de eucarionte.

- Recursos Didáticos: pensados e elaborados de acordo com as categorias de Camargo (2012a), considerando algumas questôes: os materiais deverão ser multissensoriais, econômicos e ecologicamente viáveis. A categoria comunicação irá ser utilizada com o objetivo de que a informação seja materializada, armazenada, veiculada e percebida, ou seja, será posto como norte o conhecimento adquirido a partir de experiências multissensoriais. É fundamental que se utilize em um primeiro momento, dentro dessa categoria, as estruturas fundamentais - auditivas e táteis - sendo que as estruturas visuais não serão trabalhadas com os alunos cegos, mas tratando-se de inclusão, serão fundamentais para a comunicação entre videntes e cegos. Dentro desta última perspectiva, será trabalhada, a categoria comunicação - estruturas mistas - tátil-auditiva. 
Os recursos didáticos utilizados serão principalmente o tátil e a audição, de forma que um complemente o outro, para que tanto alunos cegos, de baixa visão e videntes, compreendam as informaçóes veiculadas. No processo de educação especial a utilização de estratégias e recursos é de grande importância pois utiliza instrumentos que contemplem as características e funcionamento próprios de cada sentido (tato, olfato, audição, paladar e visão). Portanto, as atividades de ensino deverão possibilitar que o aluno deficiente visual manipule objetos e materiais que sejam os mais próximos da realidade e que facilite a compreensão dos temas.

Para que isso ocorra, é necessário que os recursos didáticos possuam diferentes estímulos, tanto táteis quanto visuais, pois dessa forma haverá inclusão, ou seja, aão somente materiais didáticos, mas sequências didáticas, que levem à total compreensão, que apresentem cores contrastantes, texturas diferentes, enfim, que se torne útil e significativo.

\section{Desenvolvimento e apresentação das atividades de ensino de Citologia sobre a Membrana Plasmática}

Como já mencionado, a ideia de "categorias" fundamenta-se nos conceitos de "representaçōes internas" ou "representaçooes mentais", que ocorrem no nível subjetivo da cognição, do pensamento. Desta forma, a principal contribuição desta pesquisa será a de propor alternativas de metodologias para o ensino de ciências em uma perspectiva inclusiva.

\section{Atividades de ensino: Membrana Plasmática}

As atividades de ensino procuraram seguir essas orientações descritas na metodologia, a partir do diálogo com os pressupostos teóricos apresentados no início do trabalho. Neste sentido, as atividades abordaram como enfoque, o componente celular mais importante, a membrana plasmática. Para que as informaçóes sobre esse tema fossem materializados, armazenados, veiculados e percebidos, é necessário ter um conhecimento adquirido a partir de experiências auditivas e táteis, ou até mesmo mistas (quando os códigos se combinam). Neste último caso, temos os significados indissociáveis, cuja representação mental é dependente de determinada percepção sensorial; esses significados nunca poderão ser representados internamente por meio de percepçôes sensoriais distintas das que os constituem. Buscando assim, o compartilhamento dos significados psicológicos, inicialmente na consciência do emissor e posteriormente na consciência do receptor.

Partindo do pressuposto de que a membrana plasmática é a unidade estrutural das células dos organismos vivos e que, essa unidade estrutural possuí três funções principais: permeabilidade seletiva, revestimento e proteção, as atividades buscaram contemplar seu total compreendimento a partir desses pontos supracitados.

\section{Atividade 1 - Permeabilidade Seletiva}

A maior parte da membrana plasmática é composta por lipídeos e proteínas, o que a confere uma composiçẫo lipoproteica, que possui uma bicamada fosfolipídica. Os fosfolipídios, dispostos nessa bicamada, 
são anfifílicos, ou seja, possuem regióes hidrofílicas (que possuem afinidade pela água) voltada para a parte externa, entrando em contato com o fluído aquoso dentro e fora da célula; e uma região hidrofóbica (sem afinidade pela água), voltada para a parte interna.

Para exemplificar essas questôes polares e apolares, foram utilizados como recursos e instrumentos os seguintes materiais: canudo, algodão, tampa de plástico (com areia que repele água) e água corada.

No canudo, foi aderido à uma de suas extremidades um algodão (representando a parte hidrofílica) e na outra extremidade uma tampa de plástico que possuí uma areia que repele água (que será explicada para os alunos em experimentos anteriores), representando a parte hidrofóbica. Ao mergulhar algodão e plástico com areia repelente em água corada (para alunos de baixa visão), tanto alunos com deficiência visual, quanto alunos videntes, poderão ter o entendimento sobre a permeabilidade seletiva da membrana plasmática, pois o algodão irá absorver a água, mas a tampa de plástico com a areia, não.

Essas colocaçôes buscam seguir as orientaçôes de Camargo (2012a), ao relacionar instrumentos táteis que envolvam também as explicaçôes auditivas, ou seja, o compreendimento da linguagem pode se dar somente através de observação simultânea com os códigos, no caso, táteis - categoria comunicaçâa - tátil e auditiva interdependentes.

\section{Atividade 2 - Proteção}

As células, além de possuírem a sua membrana plasmática, apresentam mecanismos de revestimento, que ajudam a manter sua estrutura, mas que também proporcionam uma grande proteção. Os revestimentos mais comuns encontrados em células animais são o glicocálix, que dá proteção contra agentes físicos ou químicos externos à célula e retém nutrientes ou enzimas na sua superfície.

Partindo desses pressupostos, a segunda atividade busca trabalhar com jogos de encaixe, que procuram evidenciar essa proteção e seleção que o glicocálix realiza. Para tal, foi utilizado os recursos: papelão e moldes de proteínas, bactérias, fungos, nutrientes, $\mathrm{O} 2$ (oxigênio), entre outras substancias que podem adentrar na célula.

No papelão foram realizados recortes para os moldes de diversas substancias que podem adentrar na célula. $\mathrm{O}$ intuito é que o aluno cego tente encaixar os moldes nos respectivos buracos, alguns moldes não irão encaixar, demonstrando assim, que o glicocálix protegeu a célula, enquanto ao mesmo tempo, identificou substancias úteis.

A atividade parte da análise da categoria comunicação - tátil-auditiva interdependentes e significados vinculados às representaçôes não-visuais: são significados registrados por códigos não-visuais e observados pelo tato, audição etc.; tornam-se, por este motivo, representados internamente por imagens mentais não-visuais e sempre poderão ser registrados e internamente representados por meio de códigos e representaçôes diferentes das que os constituem.

\section{Atividade 3 - Revestimento: Modelo do Mosaico Fluido}

A estrutura e revestimento da membrana plasmática é chamada comumente de modelo do mosaico fluido. De acordo com este modelo a membrana plasmática é composta por um mosaico de componentes 
(proteínas, fosfolipídios, colesterol e proteínas) que se movem livremente e com fluidez no plano da membrana. Os recursos para essa terceira atividade foram: miçangas, fio de nylon elástico e transparente e, pano de algodão mole.

Utilizamos miçangas coloridas para os alunos de baixa visão, que serão costuradas com o fio de nylon elástico no pano mole. Dessa forma o movimento de fluidez fica bem evidente e o aluno consegue associar ao movimento da membrana plasmática proposto no modelo do mosaico fluído.

Essa atividade buscou princípios da categoria comunicação - tátil e auditiva independentes, que se caracteriza pela independência entre os códigos tátil e auditivo. Dessa forma o aluno com deficiência visual entra em contato com conteúdo, através de práticas que envolvam o tato e a audição.

Até aqui está ótimo. Mas precisa fechar esse capítulo, com 1 ou 2 parágrafos, dando uma ideia de unidade ao que foi mostrado.

\section{Reflexões acerca da proposta apresentada}

Segundo Schön (1992), os profissionais aprendem partindo de análises e interpretaçóes de suas próprias atividades. Neste sentido, as práticas que nortearam o desenvolvimento das atividades de ensino, serviram para a criação de conhecimentos específicos, advindos de muita leitura. Assim, somente através do contato com a elaboração do desenvolvimento das atividades de ensino que foi possível estruturar as açóes iniciais, e partindo de um planejamento, ter conhecimentos de como agir e quais objetivos atingir. $\mathrm{O}$ ensino de ciências biológicas, de modo geral, é pautado em pressupostos visuais. Observando esses modelos regulares de aulas, foi possível realizar grandes discussôes acerca de como incluir, tanto alunos com deficiências visuais, quanto alunos videntes, para que tivessem o pleno entendimento sobre a área da ciência que mais necessita de modelos didáticos inclusivos, que é a citologia.

É importante ressaltar, que quando tratamos de deficiências visuais e os diferentes tipos que ela apresenta, nossas açóes giram em torno de paradigmas, ou seja, estamos seguindo sempre os mesmos padróes e concepçôes (MANTOAN, 2003). Quando buscamos quebrar esses paradigmas com o desenvolvimento de atividades de ensino para deficientes visuais, os nossos costumes mudam, para que a partir de tentativas específicas, o sistema educacional venha a considerar as necessidades de todos os alunos, desenvolvendo o saber juntos.

\section{Considerações Finais}

Neste trabalho foram desenvolvidas atividades de ensino na área de Biologia Celular, que contemple alunos deficientes visuais e videntes, para que dentro do contexto escolar haja inclusão. Para tanto, foi articulado junto as etapas de desenvolvimento das atividades, o referencial teórico de Camargo (2012a), que considera recursos multissensoriais, trabalhando questôes de interdependência dos sentidos, como o tato e a audição.

Este trabalho é parte de um projeto maior, que tem trabalhado com o desenvolvimento de outras atividades de ensino na área de citologia. As mesmas serão mostradas em oportunidade futura, tendo que algumas 
encontram-se em fase final de ajustes e outras passam por processos de análise após aplicaçóes. Todavia, esse ponto não minimiza a importância do texto aqui apresentado, visto que o objetivo foi cumprido na integra, ao buscar aproximar atividades inclusivas da Teoria dos Contextos Comunicacionais. Considerando que tal feito ainda é inédito na área, a fundamentação de atividades inclusivas nos pressupostos teóricos aqui mencionados, agregam valor à área e trazem subsídios para que pesquisas futuras venham a continuar do momento onde este trabalho foi finalizado.

Sendo assim, no contexto da educação inclusiva, é necessário explorar de maneira crítica outras tendências, outras respostas, outras formas de explicar e entender o mundo. Redimensionar essa atual realidade da educação excludente é uma tarefa complexa, mas existindo modelos didáticos, os profissionais poderão encontrar amparo para realizar a inclusão. Neste sentido, é necessário que que haja uma outra compreensão e análise dos alunos, em suas diferentes formas de existir.

\section{Referências}

BRASIL. Ministério da Educação. Censo Escolar. 2012, INEP, Brasília, INEP. Disponível em: <http:// www.inep.gov.br/basica/censo/Escolar/Sinopse/sinopse.asp.>. Acesso em: 15 jan. 2017.

CAIADO, K. Aluno deficiente visual na escola - lembranças e depoimentos. 2. ed. Campinas, SP: Autores associados: PUC, 2006.

CAMARGO, E.P. Ensino de Ciências e inclusáo escolar: investigaçóes sobre o ensino e a aprendizagem de estudantes com deficiência visual e estudantes surdos. Curitiba: CRV, 2016. v. 1. 232p.

CAMARGO, E.P. Saberes docentes para a inclusáo do aluno com deficiência visual em aulas de Física. 1. ed. São Paulo: Unesp, 2012a. v. 1. 260p.

CARMARGO, E.P. O Perceber e o Não Perceber: algumas reflexôes acerca do que conhecemos por meio de diferentes formas de percepção. In: MASIN, E.F.S.(org.). Perceber: raíz do conhecimento. São Paulo: Vetor, 2012b.

CAMARGO, E.P. Ensino de óptica para alunos cegos: Possibilidades. Curitiba - PR: Editora CRV, 2011. 255p

CARMARGO, E.P. A comunicação como barreira à inclusão de alunos com deficiência visual em aulas de mecânica. Ciência e Educaçáo, Bauru, v. 16, n. 1, p. 259-275, 2010.

CAMARGO, E.P. Ensino de Física e Deficiência Visual - Dez Anos de Investigaçóes no Brasil. 1. ed. São Paulo: Plêiade, 2008. v. 1. 205p.

CAMARGO, E.P.; NARDI, R. Contextos comunicacionais adequados e inadequados à inclusão de alunos com deficiência visual em aulas de Mecânica. Revista Ensaio. Belo Horizonte, v. 12, n. 2, p.2 -48, 2010.

CAMARGO, E.P.; NARDI, R. O emprego de linguagens acessíveis para alunos com deficiência visual em aulas de óptica. Revista Brasileira de Educaçáo Especial, Marília, v.14, n. 3, p.405-426, 2008. 
CAMARGO, E.P.; NARDI, R. Dificuldades e alternativas encontradas por licenciandos para o planejamento de atividades de ensino de óptica para alunos com deficiência visual. Revista Brasileira de Ensino de Física, v. 29, N. 1, 2007.

CAMARGO, E.P.; NARDI, R. Ensino de conceitos físicos de termologia para alunos com deficiência visual: dificuldades e alternativas encontradas por licenciandos para o planejamento de atividades. Revista Brasileira de Educaçáo Especial, Marília, v.12, n. 2, p.149-168, 2006 a.

CAMARGO, E.P.; NARDI, R. Planejamento de atividades de ensino de mecânica e física moderna para alunos com deficiência visual: dificuldades e alternativas. Revista electrónica de investigación en educación en ciencias, vol 1, n. 2, p. 39-64, 2006b.

CAMARGO, E.P.; NARDI, R.; CORREIA, J.N. A comunicação como barreira à inclusão de alunos com deficiência visual em aulas de Física Moderna. Revista Brasileira de Pesquisa em Educaçáo em Ciências, v.10, n.2, 2010.

CAMARGO, E.P.; NARDI, R.; VERASZTO, E.V. A comunicação como barreira à inclusão de alunos com deficiência visual em aulas de óptica. Revista Brasileira de Ensino de Física (On-line), v. 30, p. 1-13, 2008a.

CAMARGO, E.P.; NARDI, R.; VERASZTO, E.V. A comunicação como barreira à inclusão de alunos com deficiência visual em aulas de eletromagnetismo. Revista Iberoamericana de Educación (Online), v. 47, p. 1-18, 2008b.

CAMARGO, E.P.; SCALVI, L.V.A.; BRAGA, T.M.S.; VERASZTO, E.V. O ensino de Física e os portadores de deficiência visual: aspectos da relação de suas concepçóes alternativas de repouso e movimento com modelos históricos. Revista Iberoamericana de Educación (Online), v. 38, p. 1-19, 2006.

CAMARGO, E.P.; NARDI, R.; MIRANDA, N.A.; VERASZTO, E.V. Contextos comunicacionais adequados e inadequados à inclusão de alunos com deficiência visual em aulas de óptica. REEC. Revista Electrónica de Enseñanza de las Ciencias, v. 8, p. 98-122, 2009.

CARVALHO, K.M.M. et. al. Visáo subnormal - orientaçáo ao professor do ensino regular. Campinas, Unicamp, 1994.

CONDE, A.J.M. Definindo a Cegueira e a Visão Subnormal. Instituto Benjamin Constant, 2012.

DENS, A. La Educación Especial una visión sobre la integración y la inclusión desde un enfoque pedagógico. Tema livre apresentado no II Encontro Mundial de Educación Especial, Havana, Cuba, 1998.

GARCÍA, C.M. Formaçáo de professores: para uma mudança educativa. Porto: Porto Editora, 1999.

GIL, M.(Org.). Deficiência visual. Brasília: MEC/SED, p. 80, 2000.

MASINI, E.A.F.S. O perceber e o relacionar-se do deficiente visual. Coordenadoria Nacional para integraçáo da Pessoa Portadora de Deficiência (Corde), Ministério da Justiça, Brasília, 1994.

MASINI, E.A.F.S. Uma experiência de inclusão - providencias, viabilizaçáo e resultados. Educar, Curitiba, n.23, p.29-43, 2004. Editora UFPR.

MASINI, E.F.S. A educação de pessoas com deficiências sensoriais: algumas consideraçôes. In: Do sentido, pelos sentidos para o sentido: o sentido das pessoas com deficiências sensoriais. Editora Vetor, 2002. 
MANTOAN, M.T.E. Inclusão Escolar: O que é? Por quê? Como fazer? São Paulo: Moderna, 2003.

MONTEIRO, S.M. Aprender a ler e a escrever. Revista Educação: Guia da alfabetização. São Paulo: Segmento/CEALE, n.1, p.27, 2010.

PIRES, B.B.M., JORGE, V.L. Confecção de modelos biológicos para alunos cegos no segundo. Anais: I Seminário de Inclusão Escolar: práticas em diálogo, UERJ, 2014.

RODRIGUES, A.J. Contextos de Aprendizagem e Integração/Inclusão de Alunos com Necessidades Educativas Especiais. In: RIBEIRO, M.L.S., BAUMEL, R.C.R. (Org). Educaçáo Especial - Do querer ao fazer. São Paulo: Avercamp, 2003, p. 13-26.

SÁ, E.D.; CAMPOS, I.M.; SILVA, M.B.C. Atendimento Educacional Especializado: Deficiência Visual. Gráfica e Editora Cromos: Brasília, 2007. Disponível em: <http://portal.mec.gov.br/seesp/arquivos/pdf/ aee_dv.pdf >. Acesso em: 15 jan. 2017.

SANTOS, C.R.; MANGA, V.P.B.B. Deficiência Visual e Ensino de Biologia: Pressupostos Inclusivos. Revista FACEVV, no. 3, p. 13-22, 2009.

SCHÖN, D.A. Formar professores como profissionais reflexivos. In: NÓVOA, A. (coord.). Os professores e sua formação. Lisboa: Dom Quixote, 1992.

VERASZTO, E.V.; CAMARGO, E.P. Cegueira congênita e trabalho científico: um estudo sobre a percepção de professores em formação em Ciências da Natureza In: Anais. XXI Simpósio Nacional de Ensino de Física SNEF 2015, Uberlândia-MG. SBF. 2015.

VERASZTO, E.V.; CAMARGO, E.P.; CAMARGO, J.T.F. Cegueira congênita e trabalho científico: um estudo introdutório sobre a percepçáo de professores em formação. In: LOPES, N.C.; MILARE, T. (org.). Formação de Professores de Ciências: propostas de pesquisas, ensino e extensão nas licenciaturas. 1ed.Curitiba: Editora CRV, 2017, v.1, p.105-120.

VERASZTO, E.V.; CAMARGO, E.P.; CAMARGO, J.T.F. A percepção de licenciandos na área de Ciências da Natureza acerca da compreensão do conceito de luz por cegos congênitos. In: Anais. Encontro de Física 2016, XVI EPEF, Natal-RN, 2016a.

VERASZTO, E.V.; CAMARGO, E.P.; CAMARGO, J.T.F. A visáo como requisito para conhecimento de fenômenos fisicos: um estudo da opiniáo de licenciandos. In: Anais. Encontro de Física 2016, XVI EPEF, Natal-RN, 2016b.

VERASZTO, E.V.; CAMARGO, J.T.F.; CAMARGO, E.P. Trabalho científico por cegos congênitos: análise das respostas de licenciandos em cursos da área de ciências da natureza. In: Anais. Encontro de Física 2016, XVI EPEF, Natal-RN, 2016c.

VERASZTO, E. V.; CAMARGO, E. P.; MIRANDA, N. A.; CAMARGO, J. T. F. Professores em formação em Ciências da Natureza: Um estudo acerca da atuação de cegos congênitos em atividades científicas. Formação Docente, v. 06, p. 69-86, 2014.

VIGOTSKI, L.S. Obras Escogidas: V Fundamentos de Defectología. Editora Aprendizaje Visor. 2a ed. Madrid, 1997.391p. 